\title{
A spatial analysis of how growth and inequality affect poverty in Brazil
}

Helson Gomes de Souza ${ }^{1}$

Francisco José Silva Tabosa ${ }^{2}$

Jair Andrade de Araújo ${ }^{2}$

Pablo Urano de Carvalho Castelar 3

${ }^{1}$ Universidade Federal da Paraíba, João Pessoa / PB - Brazil

2 Universidade Federal do Ceará / Programa de Pós-Graduação em Economia Rural, Fortaleza / CE - Brazil

3 Universidade Federal do Ceará / Faculdade de Economia, Administração, Atuária e Contabilidade, Fortaleza / CE - Brazil

This research seeks to analyze the impacts of economic growth and income inequality on Brazilian states' urban and rural poverty, considering the effects of the initial levels of development and inequality. The elasticities of income and inequality of poverty were calculated through a dynamic spatial panel, using an adaptation of the approach developed by Kalwij and Verschoor (2004), and data from 2004 to 2014. Incorporating the spatial factor allows us to capture the effects of the geographical location on local poverty. The results suggest that a poverty reduction occurs more intensely when associated with reductions in the inequality levels. Income elasticities were greater (in absolute terms) in rural areas, while the inequality elasticities were greater in the urban area estimates. The growing trend of the inequality elasticity and the decreasing trend of the income elasticity suggest a positive trend of economic growth and a negative trend of poverty. Likewise, if the reduction in inequality shows a negative trend, the absolute value of poverty will decrease. Thus, a public policy to combat poverty through economic growth or reducing inequalities applied to the urban or rural environment would obtain more efficient results if applied in the long term.

Keywords: growth; inequality; poverty; spatial dynamic panel; Brazil.

\section{Uma análise espacial de como 0 crescimento e a desigualdade afetam a pobreza no Brasil}

A presente pesquisa busca analisar os impactos do crescimento econômico e da desigualdade de renda na pobreza urbana e rural dos estados do Brasil, considerando os efeitos dos níveis iniciais de desenvolvimento e desigualdade. Para tanto, as elasticidades da renda e a desigualdade da pobreza foram calculadas por meio de um painel dinâmico espacial, utilizando uma adaptação da abordagem desenvolvida por Kalwij e Verschoor (2004) e dados de 2004 a 2014. A incorporação do fator espacial permite capturar os efeitos da localização geográfica na pobreza local. Os resultados encontrados sugerem que a redução da pobreza ocorre mais intensamente quando associada a reduções nos níveis de desigualdade. As elasticidades de renda foram maiores (em termos absolutos) nas áreas rurais, enquanto as elasticidades de desigualdade foram maiores nas estimativas da área urbana. A tendência crescente da elasticidade-desigualdade e a tendência decrescente da elasticidade-renda encontradas sugerem que há uma tendência positiva do crescimento econômico, onde a pobreza apresentará uma tendência negativa. Da mesma forma, se a redução da desigualdade apresentar uma tendência negativa, o valor absoluto da pobreza apresentará um comportamento decrescente. Concluiu-se também que uma política pública de combate à pobreza por meio do crescimento econômico ou da redução das desigualdades aplicadas ao ambiente urbano ou rural obterá resultados mais eficientes se aplicada com maior duração.

Palavras-chave: crescimento; desigualdade; pobreza; painel dinâmico espacial; Brasil. 


\section{Un análisis espacial de cómo el crecimiento y la desigualdad afectan a la pobreza en Brasil}

La presente investigación busca analizar los impactos del crecimiento económico y la desigualdad de ingresos en la pobreza urbana y rural de los estados de Brasil, considerando los efectos de los niveles iniciales de desarrollo y desigualdad. Para ello, se calcularon las elasticidades de los ingresos y la desigualdad de la pobreza a través de un panel dinámico espacial, utilizando una adaptación del enfoque desarrollado por Kalwij y Verschoor (2004), y datos de 2004 a 2014. La incorporación del factor espacial nos permite capturar los efectos de la ubicación geográfica en la pobreza local. Los resultados encontrados sugieren que la reducción de la pobreza ocurre más intensamente cuando se asocia con reducciones de los niveles de desigualdad. Las elasticidades de la renta fueron más altas (en términos absolutos) en las áreas rurales, mientras que las elasticidades de la desigualdad fueron más altas en las estimaciones de las áreas urbanas. La tendencia creciente de elasticidad-desigualdad y la tendencia decreciente de la elasticidad ingreso encontradas sugieren que existe una tendencia positiva de crecimiento económico, donde la pobreza mostrará una tendencia negativa. Asimismo, si la reducción de la desigualdad muestra una tendencia negativa, el valor absoluto de la pobreza mostrará un comportamiento decreciente. También se concluyó que una política pública de lucha contra la pobreza mediante el crecimiento económico o la reducción de las desigualdades aplicadas al ambiente urbano o rural obtendrá resultados más eficientes si se aplica con una mayor duración.

Palabras clave: crecimiento; desigualdad; pobreza; panel dinámico espacial; Brasil.

\section{INTRODUCTION}

A recurrent theme in economic research concerns poverty, its determinants and, more importantly, how to more adequately prepare public policies aimed at decreasing the number of people living in sub-optimal conditions, deprived of basic goods and services.

Poverty in its basic concept refers to some kind of deprivation, which may be only material or also include cultural and social elements, in the face of available resources of a person or family. This deprivation may be of an absolute, relative or subjective nature (Kageyama \& Hoffmann, 2006).

In the view of Araújo, Alves and Besarria (2013), in Brazil, problems with poverty have existed since the colonization period, aggravated throughout societal development, the emergence of industry and technological advances. Although poverty is treated as a persistent phenomenon in Brazil, works by Ramos (2015) and Rocha (2006) show a decreasing trajectory of this phenomenon in periods such as the late 1990s and 2000s.

As a driving force for the negative variations in the conditions of poverty, Araújo et al. (2013) highlight the effects of economic growth and public policies of a redistributive nature. In addition, Rocha (2006) discusses the important role of education and the labor market in fighting poverty.

As Ravallion (2001) notes, economic growth plays an important role in reducing poverty levels. For the author, growth gives individuals greater possibilities of obtaining income, which provides greater chances of access to basic goods and services.

However, there are several works in the economic literature that treat economic growth as a necessary mechanism for reducing poverty, but that do not consider it to be a sufficient condition for that purpose. This approach can be seen in Annengues, Souza, Figueredo and Lima (2015), Araújo, Marinho and Campêlo (2017) and Tabosa, Irffi and Guimarães (2014). In general, these works argue that while growth acts as a mechanism to diminish poverty, this mechanism would be more efficient if applied alongside redistributive measures. 
Ney and Hoffmann (2008), furthermore, indicate that the impacts of economic growth and income concentration in Brazil can show different aspects, depending on the census situation. This perspective is analyzed by Araújo, Tabosa and Khan (2012), in a work focused on the Northeast region of Brazil. According to those authors, rural poverty is more sensitive to changes in economic growth, while urban poverty is more sensitive to changes in income inequality.

Poverty consists of a phenomenon of difficult measurement, in view of its often intangible determinants. Araújo et al. (2017), for example, consider that the initial levels of inequality and development act as determinants of poverty, and should, therefore, be considered when preparing policies aimed at decreasing the number of poor.

Using a spatial methodology, Souza, Tabosa, Araujo and Khan (2017) and Souza, Tabosa and Araujo (2019) find that poverty in Brazilian states is also affected by the effects of spatial proximity. Thus, changes in economic growth or the levels of inequality in Brazilian states would lead to a spatial spillover of poverty.

Given these considerations, this work seeks to answer the following problem: what is the impact of economic growth and income inequality on poverty in the urban and rural areas of the Brazilian states? Insight into this may prove valuable in suggesting adequate public policies to alleviate the issue in Brazil. As the economic literature seems to suggest there is more to reducing poverty than merely promoting economic growth, and that there may be a spatial aspect to the determinants of poverty, it would be a relevant contribution to study these issues more in depth.

To do so, this research takes into account the hypothesis that poverty in the urban and rural areas of the states of Brazil expresses a certain spatial dependence, causing variations in the determinants of poverty in one state of the country to cause changes in the poverty of that state and, also, in its neighboring states.

Therefore, the objective of this research is to analyze the impacts of economic growth and income inequality on urban and rural poverty in the Brazilian states, taking into account the effects of the initial levels of development and inequality. It is worth mentioning that the contribution to the academic literature proposed by this research is the innovation of the technical and methodological approach applied to the analysis of poverty, which will, arguably, be capable of providing more robust results in view of the focused problem.

The results suggest that a reduction in poverty occurs more intensely when associated with reductions in the levels of inequality. Income elasticities were greater in rural areas, while the inequality elasticities were greater in the urban area estimates. As there can be observed a growing trend in the inequality elasticity and a decreasing trend of the income elasticity, this suggests there is a positive trend of economic growth, and a negative trend in poverty. Likewise, if the reduction in inequality shows a negative trend, the absolute value of poverty will show a decreasing behavior.

Thus, the present work is subdivided into five sessions, including this brief introduction. The second, which follows, encompasses the theoretical and empirical literature foundation on which the work is based on. The third refers to the methodological framework used. The fourth discusses the results found. Lastly, the concluding remarks. 


\section{LITERATURE VIEW}

This section is intended to present a brief context of the academic literature concerning works that deal with poverty and its determinants. In this sense, the main conclusions found in these works that verify the impact of economic growth and income inequality on poverty are presented below.

\subsection{Economic Growth and Poverty}

\subsubsection{International Evidence}

There is a large number of works discussing poverty and its relationships with economic growth, such as Griffith and Nallari (2011), Ravallion (2004) and Bourguignon (2002).

Ravallion (2004) points out that economic growth generally occurs in a way that benefits those who are the poorest. The author, however, also points out that the factors that make the distribution of gains to be pro-poor, in some cases can occur in detriment to economic growth.

According to the approach of Kakwani and Pernia (2000), economic growth will only happen to the benefit of the poorest if the increase in income of that group is greater than the increase in the income of those considered to be non-poor, which would promote a reduction in inequality. Therefore, growth favors the poorest social strata if it is allied to a drop in poverty greater than it would be if all incomes had increased at the same rate.

Although poverty is more frequently seen as a consequence of low average incomes, there is reason to believe that the effects of high initial inequality also prevent future growth in favor of the poor. In many developing countries, this phenomenon can occur plausibly, due to the existence of failures that prevent some people from exploiting the development generated by growth (Ravallion, 2004).

Promoting pro-poor growth requires a deliberately biased strategy in favor of that group, so that the poor would benefit proportionately more than the rich. This result would rapidly reduce the incidence of poverty, so that those at the bottom of the consumption distribution curve would be able to meet their basic minimum needs (Kakwani \& Pernia, 2000).

Tochetto, Ribeiro, Comim and Porto (2004) indicate that there are a number of approaches that seek to explain how economic growth acts as a factor in diminishing the level of poverty, and these authors highlight a variety of elements, such as the spatial aspects of economic growth, the patterns of each economic sector, the degree of intensity and the use of factors of production, the degree of inequality of income and wealth, non-economic dimensions, the pattern and quality of public spending, and the environmental impact of growth. The authors also point out that aspects such as credit and capital market failures, the degree of dualism of the economies, distortion in the foreign exchange markets, and imperfections in other markets also play a role in converting growth into the reduction of poverty.

Bourguignon (2004) argues that a more appropriate economic development strategy should be based on income distribution and economic growth, rather than the relationship between poverty and growth only. In this sense, the author indicates that developmental measures should be directed towards the elimination of poverty through mechanisms that promote both growth and a reduction in inequalities. 
Datt, Ravallion and Murgai (2016) perform a sector analysis of the impacts of economic growth on poverty. For the authors, the decline of poverty occurs faster with higher levels of growth, which occurs in its pro-poor mode. In addition, the authors indicate that urban consumption growth drives the gains of the rural and urban poor.

Therefore, it can be seen that the literature suggests a relationship between economic growth and poverty, however, how to promote pro-poor growth will depend on the focus of public policy, and there is no homogenous answer as to how exactly economic growth impacts poverty. Since how that relationship works depends not only on how public policy is applied, but which country is being analyzed, it is worthwhile to try to establish the effects of economic growth in poverty in Brazil, as some other authors, featured below, have attempted.

\subsubsection{Evidence for Brazil}

Oliveira and Jacinto (2015) evaluate whether the recent economic growth of Brazil has favored the poorest stratum by reducing income inequality and increasing average income levels, considering different census situations. The authors conclude that there was a significant change in the quality of economic growth, benefiting mainly the urban poor. They noted, however, that this movement was accompanied by an increase in the number of states with impoverishing growth in the rural areas of the country.

Ribeiro, Araujo and Feitosa (2015) also examine the impacts of economic growth on poverty considering the urban and rural environments of the Brazilian states. In this work, the authors find that, although economic growth occurs in favor of the poorest in Brazil as a whole, only the South, Southeast and Midwest regions of the country experienced a growth pattern which reduced poverty and income inequality.

Araújo et al. (2012) demonstrate, through the calculation of the income and inequality of poverty elasticities, that in Brazil, economic growth plays a varied role in reducing poverty, depending on the census situation. The authors argue that rural poverty is more sensitive to economic growth when compared to urban poverty. Thus, as also verified by Annengues et al. (2015) and Hoffmann (2005), Araújo et al. (2012), demonstrate that economic growth becomes a more efficient mechanism for reducing poverty, be it urban or rural, if it is associated with redistributive measures.

Lastly, Ney and Hoffmann (2008) argue that rural poverty in Brazil can be reduced through economic growth, both in the rural and urban areas. The authors stress, however, the fundamental role of reducing inequalities in rural areas, so that growth must take place in order to reduce the disparities in the distribution of resources, and thus the act of diminishing rural poverty is more efficient.

Thus, the empirical evidence in Brazil seems to suggest economic growth alleviates poverty, as it usually seems to favor the poorest in society, however, there are differing conclusions if that impact is greater in urban areas or rural areas, which serves as motivation for the present work of trying to determine which is the case. 


\subsection{Income concentration and Poverty}

The other relationship explored in this work is between income inequality and poverty. Several authors have researched that relationship over the years, both in the international literature and for the Brazilian case.

\subsubsection{International Evidence}

The literature that associates the condition of poverty with the effects of inequalities in the distribution of resources is quite broad. For example, the approaches of Atkinson and Bourguignon (2014), Bourguignon (2015, 2017), Fosu (2010), Ravallion (2014) and Ravallion (2017), are some of the most referenced works.

Growth has generally helped reduce the incidence of absolute poverty, but less so in more unequal countries. High inequality also threatens to stall future progress against poverty by attenuating growth prospects. Perceptions of rising absolute gaps in living standards between the rich and the poor in growing economies are also consistent with the evidence (Ravallion, 2014).

Bourguignon (2017) analyzed inequality in income distribution and studied the social and economic determinants of the recent world economic reality that has raised the standards of living for more than half a billion people in emerging countries. For the author, an increase in people's quality of life mainly came from the reduction in disparities between the richest and the poorest social strata. Bourguignon (2017) further states that the reduction of inequality must be considered as one of the main mechanisms for reducing poverty.

Bourguignon (2004) explains that the best strategies to fight poverty are usually linked to redistribution mechanisms. This perspective was also presented by Atkinson and Bourguignon (2014).

\subsubsection{Evidence for Brazil}

Barros, Foguel and Ulyssea (2006) analyze the characteristics of inequality and its recent evolution in Brazil. The authors conclude that the behavior of the levels of income concentration observed in Brazil in the last few decades has high impact on the reduction of poverty and extreme poverty. It is also explained that this fact only occurs because a fall in income inequality only exists when the average income of the poorest grows faster than the national average income.

For Barros, Carvalho, Franco and Mendonça (2000), inequality in the distribution of income and opportunities for economic and social inclusion is the main determinant of the high levels of poverty that afflict Brazilian society. In addition, the authors point out the importance of establishing strategies to fight poverty that do not rule out economic growth, but which emphasize, above all, the role of redistributive policies that address inequality.

Barros, Carvalho, Franco and Mendonça (2010) argue that, despite the sharp decline in income distribution disparities, Brazilian income inequality remains extremely high. Moreover, they also show that improvements in the distribution of income derived from work and also non-work related income were the main factors responsible for reducing poverty levels in Brazil.

Annengues et al. (2015) developed a work in which the impacts of economic growth and income inequality in Brazil were verified considering non-parametric estimates for municipalities and Brazilian 
states. The authors suggest that, for both states and municipalities, the inequality elasticity is greater than the income elasticity, evidencing that poverty denotes greater sensitivity to changes in the levels of inequality when compared to changes in economic growth.

Araújo et al. (2012) also analyze the impact of economic growth and income inequality on poverty, by calculating the income and inequality elasticities for the urban and rural areas of the Northeastern Brazilian states. The authors show that urban poverty is more sensitive to changes in the levels of inequality compared to rural poverty. However, these authors suggest that the elasticity of inequality is generally larger than the elasticity of poverty, thus measures for the redistribution of resources in the fight against poverty are considered to be extremely important.

Thus, the literature, both international and focusing on Brazil, suggest that reducing income inequality seems to alleviate poverty, and that public policies aimed at reducing poverty should primordially feature mechanisms to decrease the distance between the richest and poorest in society. Furthermore, there seems to be a greater impact in urban poverty when income inequality is reduced than in rural areas, at least for a specific region of Brazil, the Northeast, as found by Araújo et al. (2012). This present work, then, intends to further that discussion by not only exploring the relationship between income inequality and poverty in Brazil as a whole, but analyzing the difference in the urban and rural areas of the country, and compare the results with the existing literature.

The number of people considered to be poor in Brazil showed a decreasing trend during the 1990s (Barros, 2009). This behavior is observed in Figure 1 for the years 2000 and early 2010, for both the urban and rural environments.

It is possible to see a positive correlation between the changes in the proportion of poor and income inequality in both census situations analyzed. This correlation can be explained considering the results presented by Araújo et al. (2012), which suggest that a considerable part of the variations in rural and urban poverty come from changes in income concentration.

It should be emphasized that income inequality has different effects on poverty depending on the census situation. However, Araújo et al. (2012) identify the fact that urban poverty is more sensitive to changes in the levels of inequality, while rural poverty is more sensitive to changes in economic growth.

In addition to contributing to the existing and previously cited studies on the relationships between poverty, growth and inequality in Brazil, the present work opens up a new discussion about how these relationships can be measured. Apart from considering the disaggregated analysis in terms of the census situation featured here as an important new aspect and contribution, this research tries to demonstrate that poverty, and the way it responds to changes in the levels of growth and inequality, also has a geographical focus, which is still rarely considered in the economic literature.

\section{METHODOLOGY}

To answer the queries described in the introductory section, it is necessary to use a set of techniques for the treatment of the data organized in space and time. The methodological resource used is an adaptation of the approach developed by Kalwij and Verschoor (2004), applied with econometric techniques capable of considering the effects of spatial proximity.

The basic idea in Kalwij and Verschoor (2004) is that while variation in income growth accounts for most of the variation in poverty reduction across regions, the impact of variations in inequality 
and in elasticities of poverty is frequently too large to be ignored and vary depending on the inverse of the initial level of development - which is given by the ratio of the poverty and the initial family income per capita - and the initial level of inequality.

The methodological details of the adaptation made to the approach of Kalwij and Verschoor (2004) are discussed in the following subsections.

\subsection{Spatial Proximity Matrix}

The first step to be considered is to model the neighborhood of the spatial units in a numerical way. For this purpose, a spatial proximity matrix was constructed that consists of an instrument capable of identifying neighbors of a given region by means of the representation of areas in numerical terms. Based on the specification given by Almeida (2012), the neighborhood matrix has the following structure:

$$
W_{i j}=\left\{\frac{1 \text { if } i \text { and } j \text { are neighbors }}{0 \text { if } i \text { and } j \text { are not neighbors }}\right.
$$

The matrix is constructed from a set of $n$ spaces $\left\{\mathrm{A}_{1}, \ldots, \mathrm{A}_{n}\right\}$, resulting in a $W^{(1)}(n \times n)$ matrix, where each of the $W_{i j}$ elements represandents a measure of proximity between $A_{i}$ and $A_{j}$.

\subsection{Dynamic Estimation for Spatial Panel Data}

Considering that the data are distributed in time and space, the conventional model of fixed effects is initially considered, given by:

$$
y_{t}=\alpha_{t}+X_{t} \beta+\varepsilon_{t}
$$

Where $\left\{\alpha_{1}, \ldots, \alpha_{n}\right\}$ is a vector that corresponds to fixed effects, $y$ is the dependent variable and $X$ is the matrix of independent variables. Using the procedure of incorporation of the spatial effects given by Elhorst (2010), we arrive at a general model of fixed effects that encompasses the spatial dependency including spatial lags to have control of the spatial autocorrelation, being given by:

$$
y_{t}=\alpha+\rho W_{1} y_{t}+\varepsilon_{t}+X_{t} \beta+W_{1} X_{t} \tau+\xi_{t} \quad \text { With } \quad \xi_{t}=\lambda W_{2} \xi_{t}+\varepsilon_{t}
$$

Where $W_{i} y_{t}$ is the dependent variable spatially lagged, $W_{2} \xi_{t}$ are the errors spatially lagged, $W$ is the neighborhood matrix and $\lambda$ and $\rho$ are the scalar spatial parameters, being $\tau$ a vector of spatial coefficients. The general model of random effects with spatial dependence is presented by Almeida (2012) as:

$$
y_{t}=\rho W y_{t}+X \beta+W X_{t} \tau+\xi_{t} \quad \text { With } \quad \xi_{t}=\alpha+\lambda W \xi_{t}+\varepsilon_{t}
$$

In this work, the estimates made presuppose that poverty does not respond immediately to shifts in economic growth and income inequality, given the necessity for time for the absorption of changes 
in these variables. Almeida (2012) indicates that this specification can be made by inserting the time lag of the dependent variable in the set of regressors.

Almeida (2012) argues that, in this procedure, there are two sources of endogeneity: spatial endogeneity, which occurs because of $E\left(W_{1} y_{t} \varepsilon_{t}\right) \neq 0$; and the time endogeneity, which occurs because of $E\left(y_{t-1} \varepsilon_{t}\right) \neq 0$.

A conventional estimator of dynamic models for panel data with spatial specification as given in Equation (5), however, eliminates the fixed effects through the process of differentiation of the variables.

$$
\Delta \mathrm{yt}=\rho \Delta W y_{t-j}+\delta \Delta y_{t-j}+\Delta X_{t} \beta+\Delta W X_{1} \tau+\Delta \varepsilon_{t}
$$

Although equation (5) eliminates the fixed effects in the differentiation process, as mentioned in Araújo, Gonçalves and Almeida (2015), the time lagged dependent variable is still endogenous, since $y_{t-j}$ is correlated with $\varepsilon_{t}$. Arellano and Bover (1995) and Blundell and Bond (1998) suggest, then, the use of the System-GMM estimator for a dynamic panel.

This estimator uses instruments to form the momentum conditions and makes the modeling structure more efficient, dealing with the unobserved fixed effects and with the problem of endogeneity present in the time lag of the dependent variable. Thus, the lags in the dependent variable in level are instruments for the first difference equation, and the lags of the variables in first difference are valid instruments for the equation in level. The consistency of that method is given by the fact that these instruments are not correlated with the error term (Araújo et al., 2015).

To correct the spatial endogeneity, we use the Kukenova and Monteiro (2009) procedure, so we estimate Equation (5) by means of the Generalized Method of Moments in its systemic form, using only the specification of the space Lag model, in which $\rho \neq 0, \tau=0$ and $\lambda=0$.

In this procedure, spatial and time lags are used to instrumentalize $\Delta W y_{t}$ and $\Delta y_{t-1}$. As indicated by Araújo et al. (2015), the lags of the dependent variable in level are instruments for the equation in the first difference, and the lags of these variables in first difference are valid instruments for the equation in level.

According to Araújo et al. (2017), an independent variable is strictly exogenous if it is not correlated with past, present, and future error terms; weakly exogenous if it is only correlated with the past error terms; and endogenous if it is correlated with past, present or future errors. In this sense, the explanatory variables of the models estimated afterwards are subdivided into two groups, being the set of instruments, containing the spatial and time lags of the dependent variable and the explanatory variables, endogenous to the model.

Almeida (2012) indicates that the consistency of the GMM method is verified by the Sargan statistic.

In order to find the value of the income and inequality of poverty elasticities, a spatial approach was used for the dynamic model specified by Kalwij and Verschoor (2004).

The inclusion of the time aspect in the estimations implies obtaining dynamic results, not just static ones. The incorporation of the spatial factor allows us to capture the effects of the geographical location on local poverty. In this sense, the correction of endogeneity through the instrumentation 
of the endogenous regressors is done considering the specification of Araújo et al. (2015) ${ }^{1}$, which use two time and spatial lags as instruments in a spatial dynamic estimation. In this work, up to two lags are used, so that the validity of the instruments will be verified through the Sargan statistic.

In order to establish the number of spatial lags, a spatial weights matrix was used to provide a better fit for the model, as done by Araújo et al. (2015). This procedure is based on LeSage and Pace (2010), which demonstrated that the choice of the spatial weight matrix does not change the marginal effects of the estimates, considering that the most important is the adequate specification of the model ${ }^{2}$.

For the estimation referring to the quadratic urban poverty gap, two spatial lags and a one period lag were used to instrumentalize the endogenous components of the model referring to the proportion of poor in relation to the other estimates, a spatial lag and a one period lag were used.

In this research, we seek to capture the impacts of income inequality and economic growth on a set of poverty indicators. We follow the procedure featured in Kalwij and Verschoor (2004), which indicate that poverty varies as its interactions with growth, inequality and development change. Adapting Equation 5 to the Kalwij and Verschoor (2004) approach considering the GMM method, we obtain:

$$
\begin{aligned}
\Delta \ln P j_{i t}=\beta_{0} & +\rho \Delta W \ln P j_{i t-j}+\delta \Delta \ln P j_{i t-j} \\
& +\beta_{1} \Delta \ln \left[\bar{y}_{i t}\right]+\beta_{2}\left[\Delta \ln [\bar{y}] \ln G_{i t-1}\right]+\beta_{3}\left[\Delta \ln \left[y_{i t}\right] \ln \left[Z_{i t} / \bar{y}_{i t-1}\right]\right] \\
& +\beta_{4} \Delta \ln G_{i t}+\beta_{5}\left[\Delta \ln \left[G_{i t}\right] \ln \left[G_{i t-1}\right]\right] \\
& +\beta_{6}\left[\Delta \ln \left[G_{i t}\right] \ln \left[Z_{i t} / \bar{y}_{i t-1}\right]\right]+\beta_{7} \ln G_{i 0}+\beta_{8}\left[\ln \left[Z_{i t} / \bar{y}_{i t-1}\right]\right] \\
& +\Delta \varepsilon_{t}
\end{aligned}
$$

Where $P J$ is the poverty indicator used with $j=0,1,2 ; \bar{y}$ is the average family income per capita, $G$ is the income inequality represented by the Gini index; $\left[\Delta \ln [\bar{y}] \ln G_{i t-1}\right]$ and $\Delta \ln \left[y_{i t}\right] \ln \left[Z_{i t} \mid \bar{y}_{i t-1}\right]$ represent respectively, the interactions between the variation of the average family income per capita and the initial Gini index for state $i$; and the inverse of the initial level of development $Z_{i t} / \bar{y}_{i t-1}$ (poverty line divided by the initial family income per capita); $\left[\Delta \ln \left[G_{i t}\right] \ln \left[G_{i t-1}\right]\right]$ and $\left[\Delta \ln \left[G_{i t}\right] \ln \left[Z_{i t} / \bar{y}_{i t-1}\right]\right.$ represent, respectively, the interactions between the Gini inequality index and the initial inequality index of state $I$, and the inverse of the initial level of development.

In order to obtain the income and inequality elasticities, it is necessary to consider the effects of these interactions, thus:

$$
\begin{gathered}
\varepsilon_{\bar{y}_{i t}}^{P_{0,1,2}}=\beta_{1}+\beta_{2} \ln \left[G_{i t-1}\right]+\beta_{3} \ln \left[Z_{i t} / \bar{y}_{i t-1}\right] \\
\varepsilon_{G_{i t}}^{P_{0,1,2}}=\beta_{4}+\beta_{6} \ln \left[Z^{Z_{i t}} / \bar{y}_{i t-1}\right]
\end{gathered}
$$

\footnotetext{
${ }^{1}$ Estimates were made with the matrices of the type Queen, Rook and $K$ neighbors with $K=1 ; K=2 ; K=3 ; K=4 ; K=5$ and $K=10$. ${ }_{2}^{2}$ For the estimates outlined in Table 1, a Queen-type contiguity matrix was used, since this matrix showed greater data suitability and greater validity of the instruments.
} 
Where $\varepsilon_{\bar{y}_{i t}}^{P_{0,2}}$ and $\varepsilon_{G_{G_{u}}}^{P_{0,2}}$ are, respectively, the income elasticity and the inequality elasticity in their dynamic form. As the models estimated according to Equation 6 have interactions between the explanatory variables - which are in logarithmic form -, the calculation of income and poverty inequality elasticities shown in Equation 7 is given by the total derivative of Equation 6 in relation to the indicators of poverty and inequality, following the specification of Kalwij and Verschoor (2004).

\subsection{Data}

To indicate the poverty level, $P 0, P_{1}$ and $P_{2}$ are used, which are given by:

$$
P_{0}=\frac{q}{n} \quad P_{1}=\frac{1}{q} \sum_{i=1}^{q}\left(\frac{z-y_{i}}{z}\right) \quad P_{2}=\frac{1}{q}\left(\frac{z-y_{i}}{z}\right)^{2}
$$

Where informs the proportion of the poor, $q$ represents the quantity of the poor, $n$ represents the number of individuals, $z$ denotes the poverty line and $y$ is the family income per capita (updated for the year 2015 using the National Consumer Price Index - Índice Nacional de Preços ao Consumidor - INPC). For the construction of this index an individual is considered to be poor if that person has income which is lower than the poverty line. The poverty line is the one used by the Institute of Labor and Society Studies (Instituto de Estudos do Trabalho e Sociedade - IETS). The inequality in the distribution of income is measured by the Gini index and the family income per capita is used as a proxy for economic growth.

The data used were obtained through the National Survey by Household Sample (Pesquisa Nacional por Amostra de Domicílios - PNAD), made available annually by the Brazilian Institute of Geography and Statistics (Instituto Brasileiro de Geografia e Estatística - IBGE) In view of the non-availability of the PNAD database for the year 2010, the figures for that year were obtained by means of the arithmetic average of the previous and successive years.

The choice of the PNAD as a data source was due to its annual periodicity and its national scope. The data are available over a period of 11 years (2004 to 2014). It should be emphasized that the use of this period is due to the availability of the information regarding the rural environment for all the Brazilian states. The analyses are done for the rural and urban environments, being delimited by the PNAD by each of the 26 units of the Brazilian Federation, including also the Federal District.

\section{RESULTS}

In this section we present the results found with the method used, as well as the discussions with the existing framework in the literature about the theme.

Observing Figure 1, it is also possible to note that poverty, whether in the urban or rural areas of Brazil, shows a downward trend that is greater than the decrease in the levels of inequality. Visually, it is verified that, although it has decreased during the analyzed period, the concentration of income is a phenomenon more persistent and less volatile than the poverty. 
0,6

0,5

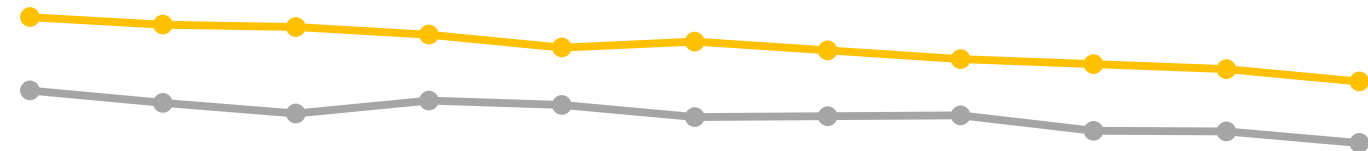

0,4

0,3

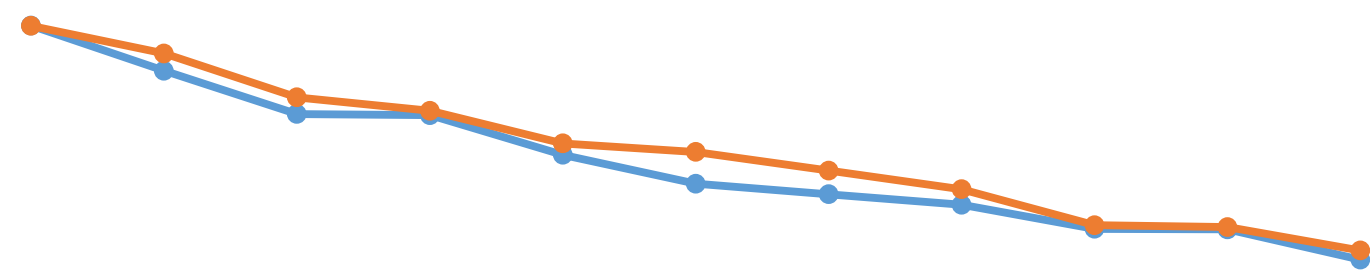

0,1

0

\begin{tabular}{|c|c|c|c|c|c|c|c|c|c|c|}
\hline 2004 & 2005 & 2006 & 2007 & 2008 & 2009 & 2010 & 2011 & 2012 & 2013 & 2014 \\
\hline
\end{tabular}

Source: Elaborated by the authors.

The results of the model estimates proposed in the previous section are shown in Table 1. In relation to the urban environment, the first-order time component presented a negative sign and was statistically significant, confirming the hypothesis of the persistence of poverty, as found by Araújo et al. (2017).

In relation to the first order spatial lag, the coefficient was positive and statistically significant for the proportion of the poor and the poverty gap, which indicates the existence of a spatial overflow of poverty in the urban area. For the quadratic hiatus, the spatial component is positive only after the insertion of two lags. This behavior was also found by Araújo et al. (2015) for industrial activities in Brazil, and by Paci and Usai (2008), for the Italian industrial sector.

The authors attribute the negative sign of the first order spatial lag to the effect of the polarization of industrial activities. With respect to the quadratic hiatus of poverty, the negative sign of the first order spatial lag can come from the differences in income in the urban environment of the Brazilian states.

As for the economic growth and its interactions with the inverse of the initial development, it is verified that the sign is positive for the proportion of poor (0.9723) and for the quadratic hiatus of poverty (3.7026), and there is statistical significance for these indicators. This result indicates that, in the urban environment, changes in economic growth lead to greater reductions in the levels of poverty in areas where the initial level of development is higher, as verified by Araújo et al. (2017) for the Brazilian states. 
Regarding the rural environment, it is verified that, in relation to the proportion of poor, the time lag expressed statistical significance and a negative sign, as verified by Tabosa, Castelar and Irffi (2016) and Araújo et al. (2017) for Brazil as a whole, indicating that, in rural areas, poverty presents an intertemporal persistence.

Comparing the values of the time lag coefficients for the rural indicators with the coefficients obtained for this same variable in the urban environment, it is verified that these values are greater for the rural poverty indicators, which suggests that the persistence of poverty occurs in a more intense way in this census situation.

In addition, in relation to the poverty gap, it is observed that the coefficient of the interactions of economic growth with the initial inequality in the rural environment shows that changes in income levels reduce the distance between the income of the poor and the poverty line in greater magnitude in areas where the initial inequality is lower ${ }^{3}$.

\section{TABLE $1 \quad$ RESULTS OF THE ESTIMATES FOR THE POVERTY INDICATORS}

\begin{tabular}{|c|c|c|c|}
\hline \multicolumn{4}{|c|}{ Urban area } \\
\hline & P0 (queen) & P1(queen) & P2 (queen) \\
\hline Constant & -0.2154 & -0.0531 & -0.1834 \\
\hline Spatial lag $t_{t-1}$ & $0.1515^{\star}$ & $0.3201^{*}$ & -0.0007 \\
\hline Time $\operatorname{lag}_{t-1}$ & $-0.2119^{\star}$ & $-0.2351^{*}$ & $-0.3348^{*}$ \\
\hline Spatial lag $g_{t-2}$ & - & - & $0.0001^{*}$ \\
\hline$\Delta \ln \left[\bar{y}_{i t}\right]$ & 1.6968 & 0.2752 & 2.7198 \\
\hline$\Delta \ln [\bar{y}] \ln G_{i t-1}$ & $3.1317^{\star *}$ & $4.2292^{\star *}$ & $9.7948^{\star}$ \\
\hline$\Delta \ln \left[y_{i t}\right] \ln \left[Z_{i t} \mid \bar{y}_{i t-1}\right]$ & $0.9723^{\star \star \star}$ & -0.7272 & $3.7036^{\star}$ \\
\hline$\Delta \ln G_{i t}$ & $-3.8248^{\star \star \star}$ & -1.2315 & -2.6399 \\
\hline$\left[\Delta \ln \left[G_{i t}\right] \ln \left[G_{i t-1}\right]\right]$ & $-6.0711^{\star \star \star}$ & $-9.6894^{\star \star \star}$ & $-15.2941^{*}$ \\
\hline$\left[\Delta \ln \left[G_{i t}\right] \ln \left[Z_{i t} \mid \bar{y}_{i t-1}\right]\right]$ & $-2.0671^{\star \star \star}$ & $1.9633^{\star \star}$ & $3.7036^{\star}$ \\
\hline $\ln G_{i t-1}$ & $-0.3241^{*}$ & -1.2315 & -0.6227 \\
\hline$\left[\ln \left[Z_{i t} \mid \bar{y}_{i t-1}\right]\right]$ & -0.0575 & 0.1020 & 0.1255 \\
\hline Sargan test & $\begin{array}{c}277.636 \\
(\text { Prob }=0.1914)\end{array}$ & $\begin{array}{c}245.962 \\
(\text { Prob }=0.6946)\end{array}$ & $\begin{array}{l}233.272 \\
(0.6448)\end{array}$ \\
\hline
\end{tabular}

\footnotetext{
${ }^{3}$ It should be noted that the coefficients obtained for the variable may show a negative sign in the results in Table 1, since inequality is
} linked to other variables in the model through interactions, making not the true coefficient associated with the Gini index. 


\begin{tabular}{|c|c|c|c|}
\hline \multicolumn{4}{|c|}{ Rural area } \\
\hline & P0 (queen) & P1 (queen) & P2 (queen) \\
\hline Constant & $-0.5385^{\star \star}$ & -0.1261 & 0.2726 \\
\hline Spatial lag $g_{t-1}$ & $0.1972^{\star \star \star}$ & $0.1951^{*}$ & 0.0012 \\
\hline Time $\operatorname{lag}_{t-1}$ & $-0.2249^{\star \star \star}$ & $-0.2683^{\star}$ & $-0.3820^{\star}$ \\
\hline$\Delta \ln \left[\bar{y}_{i t}\right]$ & $2.2329^{*}$ & 3.0517 & 4.0492 \\
\hline$\Delta \ln [\bar{y}] \ln G_{i t-1}$ & $2.4219^{\star}$ & $5.1207^{*}$ & $7.2587^{\star}$ \\
\hline$\Delta \ln \left[y_{i t}\right] \ln \left[Z_{i t} \mid \bar{y}_{i t-1}\right]$ & $2.0969^{\star \star \star}$ & -1.2002 & 0.8890 \\
\hline$\Delta \ln G_{i t}$ & 0.2036 & 0.9970 & -1.8688 \\
\hline$\left[\Delta \ln \left[G_{i t}\right] \ln \left[G_{i t-1}\right]\right]$ & 0.9401 & -0.9758 & -5.7569 \\
\hline$\left[\Delta \ln \left[G_{i t}\right] \ln \left[Z_{i t} \mid \bar{y}_{i t-1}\right]\right]$ & $-2.5166^{\star}$ & -1.2002 & -0.9170 \\
\hline $\ln G_{i t-1}$ & $-0.5621^{*}$ & -0.2715 & 0.1310 \\
\hline$\left[\ln \left[Z_{i t} \mid \bar{y}_{i t-1}\right]\right]$ & $-0.2066^{\star}$ & -0.1075 & -0.9170 \\
\hline Sargan test & $\begin{array}{c}266.928 \\
(\text { Prob }=0.3380)\end{array}$ & $\begin{array}{c}237.469 \\
\text { (Prob }=0.8158)\end{array}$ & $\begin{array}{c}230.176 \\
\text { (Prob }=0.8929)\end{array}$ \\
\hline
\end{tabular}

Note: Values followed by $\left(^{*}\right)$ are significant at the $5 \%$ level. Source: Elaborated by the authors.

With the results outlined in Table 1, it is possible to obtain the income and inequality of poverty elasticities in their dynamic aspect. The results of this procedure are outlined in Table 3, in the appendix. To facilitate interpretation and visualization, Table 2 shows the dynamic elasticities for Brazil and its large regions in terms of averages.

The results obtained with the dynamic elasticities corroborate what was demonstrated in the works of Annengues et al. (2015), Barros et al. (2006), Araújo et al. (2017), Hoffmann (2005), Araújo et al. (2012) and Souza et al. (2019), which suggest that the reduction of poverty occurs more intensely when associated with reductions in the inequality levels.

Income elasticities were greater (in absolute terms) in rural areas, while the inequality elasticities were greater in the urban area estimates, as also observed by Araújo et al. (2012). This fact indicates that a public policy of fighting poverty through economic growth will have greater effects in rural areas, while a policy of fighting poverty based on the reduction of disparities will achieve better results in the urban environment. 


\section{TABLE 2 INCOME AND INEQUALITY OF POVERTY ELASTICITIES IN AVERAGE VALUES}

\begin{tabular}{|c|c|c|c|c|c|c|}
\hline & \multicolumn{6}{|c|}{ Urban area } \\
\hline & \multicolumn{2}{|c|}{ PO } & \multicolumn{2}{|c|}{ P1 } & \multicolumn{2}{|c|}{ P2 } \\
\hline & INCE & INQE & INCE & INQE & INCE & INQE \\
\hline Brazil & -1.4826 & 2.5573 & -2.7176 & 3.8697 & -4.2705 & 5.3822 \\
\hline North & -1.3866 & 2.3474 & -2.7600 & 4.2241 & -4.5897 & 6.0210 \\
\hline Northeast & -1.1416 & 1.8612 & -2.5109 & 3.7757 & -4.1177 & 5.3508 \\
\hline Southeast & -1.7954 & 3.2051 & -2.8406 & 3.7042 & -4.1713 & 4.9831 \\
\hline South & -2.2863 & 4.2115 & -3.1096 & 3.7314 & -4.2885 & 4.8447 \\
\hline \multirow[t]{4}{*}{ Center-West } & -1.5022 & 2.6027 & -2.6911 & 3.7299 & -4.1413 & 5.1373 \\
\hline & \multicolumn{6}{|c|}{ Rural area } \\
\hline & \multicolumn{2}{|c|}{ PO } & \multicolumn{2}{|c|}{ P1 } & \multicolumn{2}{|c|}{ P2 } \\
\hline & INCE & INQE & INCE & INQE & INCE & INQE \\
\hline Brazil & -1.8569 & 2.6677 & -5.4961 & - & -5.5955 & - \\
\hline North & -1.8726 & 2.8204 & -5.3491 & - & -5.2614 & - \\
\hline Northeast & -1.0928 & 1.7207 & -4.9991 & - & -5.6703 & - \\
\hline Sotheast & -2.3350 & 3.1609 & -5.9243 & - & -5.7966 & - \\
\hline South & -3.1579 & 4.0235 & -6.6453 & - & -6.1089 & - \\
\hline Center-West & -2.0948 & 3.0212 & -5.5816 & - & -5.4258 & - \\
\hline
\end{tabular}

Note: INCE = Income Elasticity; INQE = Inequality Elasticity.

Source: Elaborated by the authors.

Figure 2 shows the behavior of the income and inequality elasticities of the proportion of poor in urban and rural areas in Brazil by means of the calculation of the annual averages of the elasticities. It is possible to visualize an increasing tendency of the inequality elasticities, while the income elasticities denote a decreasing behavior. This result suggests that poverty is becoming more sensitive to changes in economic growth and inequality levels.

It is worth mentioning a simple, but important observation, related to the results shown in Figure 2. The academic contributions regarding the relationships between poverty, growth and inequality related to Brazil show an inverse relationship between poverty and growth, and a positive relationship between poverty and inequality, as can be seen in Araújo et al. (2012) and Souza et al. (2019).

The growing trend of the inequality elasticity and the decreasing trend of the income elasticity of poverty in Figure 2 represents evidence that, in the periods analyzed, there is a positive trend of economic growth, where poverty will show a negative trend. Likewise, if the reduction in inequality shows a negative trend, the absolute value of poverty will show a decreasing behavior. 
From an economic point of view, this result leads us to conclude that public policies aimed at fighting poverty through economic growth or the reduction of inequalities will achieve greater results if applied with a longer duration, given the trends in the elasticities mentioned above.

FIGURE 2 AVERAGE ANNUAL INCOME AND INEQUALITY ELASTICITIES OF THE PROPORTION OF THE POOR

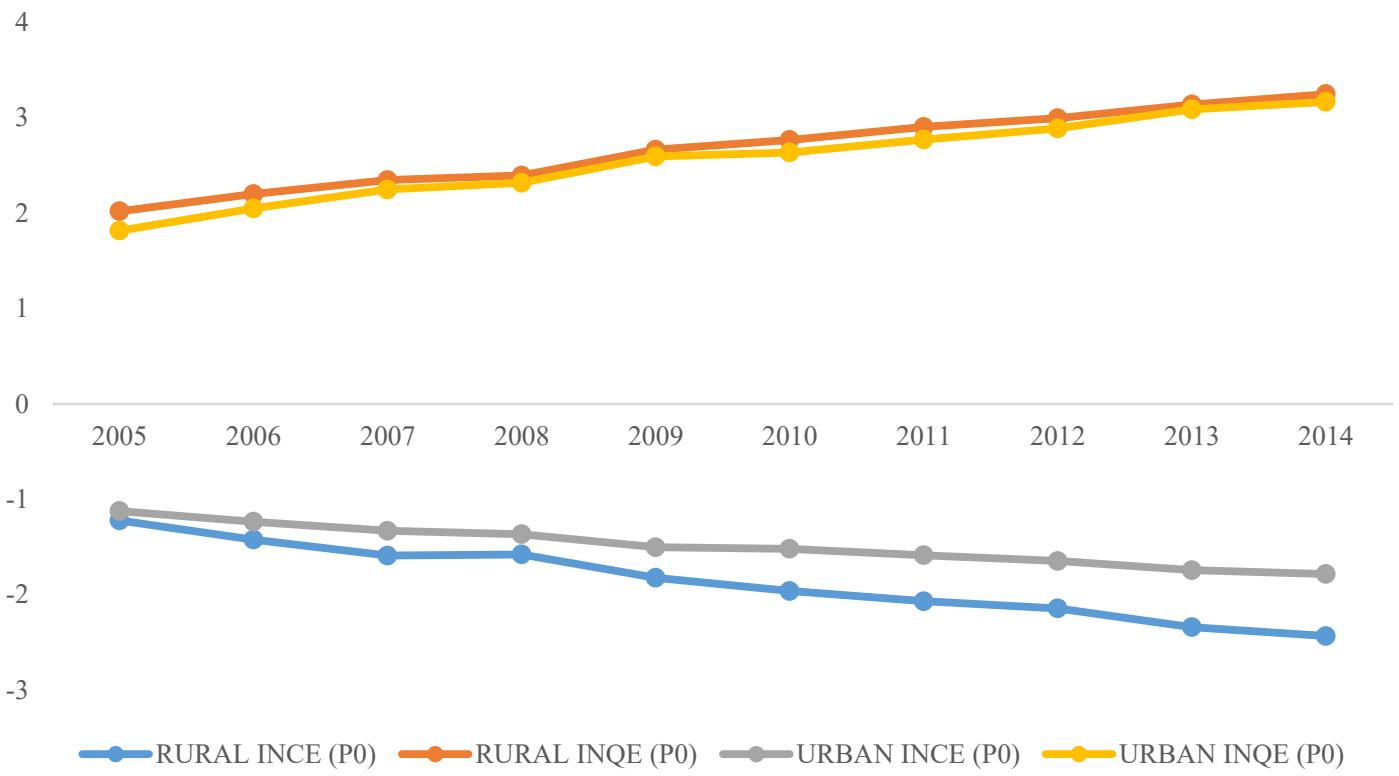

Note: INCE = Income Elasticity; INQE = Inequality Elasticity.

Source: Elaborated by the authors using data from PNAD - IBGE.

In light of these observations, we reinforce the conclusions made in the literature cited previously, where economic growth is, indeed, an important factor in reducing poverty, however, public policies aimed at reducing the levels of poverty will have greater effects when associated with redistributive measures.

Another relevant point to highlight is that the reduction of poverty, stemming from economic growth and the reduction of inequality, can occur due to different reasons, such as direct income transfer policies (like the Bolsa Familia Program, for example), the real increase in the minimum wage during the analyzed period, a decrease in the unemployment rate, and low levels of inflation aligned with economic stability (Tabosa et al., 2016). 


\section{CONCLUDING REMARKS}

This work aimed to analyze the impacts of economic growth and income inequality on the urban and rural poverty of the states of Brazil, taking into account spatial and time effects. To do so, an econometric approach was used to obtain the dynamic behavior of the income and inequality elasticities of poverty, through a spatial dynamic panel.

By inserting the spatial component in the estimates, there was an overflow of poverty in the urban and rural areas of the Brazilian states. The inclusion of the time component has allowed us to conclude that poverty expresses a behavior of persistence, both in the urban and rural environments.

In support of the results found, it was observed that rural poverty is more sensitive to changes in economic growth, while poverty in the urban environment shows greater sensitivity to changes in the levels of income inequality.

Through interactions between economic growth and the initial level of development, it has been found that changes in the economic growth of urban areas lead to further reductions in the levels of poverty in areas where the initial level of development is highest.

By calculating the dynamic elasticities, it was found that economic growth is an important mechanism for reducing poverty. It is noted, however, that poverty reduction, whether urban or rural, occurs more intensively when associated with reductions in the levels of inequality.

It was also concluded that a public policy of fighting poverty through economic growth or the reduction of inequalities applied to the urban or rural environment will obtain more results if applied with a longer duration.

Lastly, the importance of economic growth and the reduction of disparities in the application of measures to fight poverty requires attention. It also seems to be the case that there is necessary to include the effects of the initial levels of development and inequality in the formulation of means to reduce the levels of poverty.

The decrease in poverty can occur due to direct income transfer policies, real increase in the minimum wage during the period analyzed, a reduction in the unemployment rate, low levels of inflation and economic stability. This scenario has become conducive to economic growth and the reduction of income inequality in the country (Tabosa et al., 2016)

It is important to highlight some limitations that the present work has, as well as to indicate that future changes can be made and which paths should be taken by researchers who wish to study different segments of this topic:

\section{Limitations:}

- This work calculates the income and inequality elasticities of poverty for Brazil using a spatial approach. However, the measurement of poverty occurs only in a one-dimensional form. It is suggested that future works should aim to address this issue.

- The unavailability of more disaggregated data in a continuous frequency of time prevents an analysis at a level of disaggregation below the state scale.

- The model used here is unable to provide information on elasticities in the event that a migratory movement of poverty occurs between the census situations analyzed. 
RAP | A spatial analysis of how growth and inequality affect poverty in Brazil

\section{Suggestions for future works:}

- For researchers who are interested in continuing this research, filling in the gaps left by the limitations existing in the period in which this work was crafted, it would be interesting to seek a way to calculate the income and inequality elasticities of poverty considering the direct, indirect and total effects of spatial autocorrelation.

- It is also suggested that some controls be applied to the model, which would make it possible to reduce the estimation error, as well as provide more robust results to the estimations. 


\section{REFERENCES}

Almeida, E. (2012). Econometria espacial aplicada. Campinas, SP: Alínea.

Annengues, A. C., Souza, W. P. S. F., Figueredo, E., \& Lima, F. S. (2015). Elasticidade da pobreza: aplicação de uma nova abordagem empírica para o Brasil. Planejamento E Políticas Públicas, 44, 145-166.

Araújo, I. F., Jr., Gonçalves, E., \& Almeida, E. (2015). Efeitos de externalidades dinâmicas e espaciais sobre o crescimento local: evidências do Brasil (1995-2013). In Anais do $43^{\circ}$ Encontro Nacional De Economia, Florianópolis, SC.

Araújo, J. A., Marinho, E., \& Campêlo, G. L. (2017, diciembre). Crecimento económico y concentración del ingreso: sus efectos em la pobreza del Brasil. Revista De La Cepal, 123, 37-57.

Araújo, J. A., Tabosa, F. J. S., \& Khan, A. S. (2012). Elasticidade renda e elasticidade desigualdade da pobreza no nordeste brasileiro. Revista De Política Agrícola, 21(1), 50-59.

Araujo, J. M., Alves, J. A., \& Besarria, C. N. (2013). $\mathrm{O}$ impacto dos gastos sociais sobre os indicadores de desigualdade e pobreza nos estados brasileiros no período de 2004 a 2009. Revista De Economia Contemporânea, 17(2), 249-275.

Arellano, M., \& Bover, O. (1995). Another Look At The Instrumental Variable Estimation Of ErrorComponents Models. Journal Of Econometrics, 68(1), 29-51.

Atkinson, A. B., \& Bourguignon, F. (2014). Handbook of income distribution. Amsterdam, Netherlands: Elsevier.

Barros, R., Carvalho, M., Franco, S., \& Mendonça, R. (2010). Determinantes da queda na desigualdade de renda no Brasil (Texto Para Discussão No 1460). Brasília, DF: Instituto de Pesquisa Econômica Aplicada.

Barros, R. P. D., Foguel, M. N., \& Ulyssea, G. (2006). Desigualdade de renda no Brasil: uma análise da queda recente. Brasília, DF: Instituto de Pesquisa Econômica Aplicada.

Barros, R. P. D., Henriques, R., \& Mendonça, R. (2000). Desigualdade e pobreza no Brasil: retrato de uma estabilidade inaceitável. Revista Brasileira De Ciências Sociais, 15(42), 123-142.
Blundell, R., \& Bond, S. (1998). Initial conditions and moment restrictions in dynamic panel data models. Journal Of Econometrics, 87(1), 115-143.

Bourguignon, F. (2004). The Social Consequences Of Economic Growth. In P. Aghion, \& S. Durlauf (Eds.), The Handbook Of Economic Growth. Amsterdam, Netherlands: Elsevier, 2004.

Bourguignon, F. (2014). The growth elasticity of poverty reduction: explaining heterogeneity across countries and time periods. In T. S. Eicher, \& S. J. Turnovsky (Eds.), Inequality and Growth: Theory and Policy Implications (pp. 3-26). Cambridge, MA: MIT Press.

Bourguignon, F. (2015). Appraising income inequality databases in Latin America. Journal of Economic Inequality, 13(4), 557-578.

Bourguignon, F. (2017). The globalization of inequality. Princeton, NJ: Princeton University Press.

Datt, G., Ravallion, M., \& Murgai, R. (2016, September). Growth, urbanization and poverty reduction in India (Discussion Paper). Melbourne, Australia: Monash Business School.

Eicher, T. S., \& Turnovsky, S. J. (2002). Inequality and growth: theory and policy implications. Cambridge, UK: The Mit Press.

Elhorst, J. P. (2010). Applied spatial econometrics: raising the bar. Spatial Economic Analysis, 5(1), 9-28.

Elhorst, J. P. (2014). Spatial econometrics from cross-sectional data to spatial panels. London, UK: Springer.

Fosu, A. K. (2010). Growth, inequality, and poverty reduction in developing countries: recent global evidence (Working Paper, No 2011/01). Helsinki, Finland: Instituto Mundial De Investigaciones De Economía Del Desarrollo (Unu-Wider).

Griffith, B., \& Nallari, R. (2011). Understanding growth and poverty theory, policy, and empirics. Washington, DC: The World Bank.

Instituto de Pesquisa Econômica Aplicada. (2019). IpeaData. Retrieved from www.ipeadata.gov.br/ default.aspx

Kageyama, A., \& Hoffmann, R. (2006). Pobreza no Brasil: uma perspectiva multidimensional. Economia E Sociedade, 15(1) 79-112. 
Kakwani, N., \& Pernia, E. M. (2000). What is propoor growth? Asian Development Review, 18(1), 1-16.

Kalwij, A., \& Verschoor, A. (2004, November). How good is growth for the poor? The role of the initial income distribution in regional diversity in poverty trends (Working Paper Series, N. 115). Tilburg, The Netherlands: University Tilburg.

Kukenova, M., \& Monteiro, J. A. (2009). Spatial dynamic panel model and system GMM: a Monte Carlo investigation. Munich, Germany: University Library Of Munich.

Lesage, J. P., \&; Fischer, M. M. (2008, November). Spatial growth regressions: model specification, estimation and interpretation. Spatial Economic Analysis, 3(3), 275-304.

Lesage, J. P., \& Pace, R. K. (2010). The biggest myth in spatial econometrics. Social Science Research Network, 2(4), 217-249.

Ney, M. G., \& Hoffmann, R. (2008). A contribuição das atividades agrícolas e não-agrícolas para a desigualdade de renda no Brasil rural. Economia Aplicada, 12(3), 365-393.

Oliveira, V. R., \& Jacinto, P. A. (2015). Crescimento Pró-Pobre Ou Empobrecedor? Uma Análise Para Os Estados Brasileiros, No Período 1995-2011. Nova Economia, 25(1), 161-180.

Paci, R., \& Usai, S. (2008). Agglomeration economies, spatial dependence and local industry growth. Revue D'économie Industrielle, 123, 87-109.

Ramos, C. A. (2015). A queda da pobreza e da concentração de renda no brasil. "À la Recherche" da teoria perdida. Nova Economia, 25(3), 599-620.

Ravallion, M. (2004). Pro-poor growth: a primer (Policy Research Working Papers, N. 3242). Washington, DC: The World Bank.
Ravallion, M. (2011). Growth, inequality and poverty: looking beyond averages. World Development, 29(11), 1803-1815.

Ravallion, M. (2014). Income inequality in the developing world. Science, 344(6186), 851-855.

Ravallion, M. (2017). Inequality and globalization: a review essay. Journal Of Economic Literature, 56(2), 620-642.

Ribeiro, L. L., Araujo, J. A., \& Feitosa, D. G. (2015, abril). Crescimento pró-pobre? Uma análise para os meios urbano e rural no Brasil. Pesquisa $E$ Planejamento Econômico, 45(1), 155-176.

Rocha, S. (2006). Pobreza e indigência no brasil algumas evidências empíricas com base na PNAD 2004. Nova Economia, 16(2), 265-299.

Souza, H. G., Tabosa, F. J., Araujo, J. A., \& Khan, A. S. (2017, agosto). Análise espaço-temporal da pobreza nos estados brasileiros. Revista De Desenvolvimento Econômico, 2(37), 212-232.

Souza, H. G., Tabosa, F. J. S., \& Araujo, J. A. (2019). Elasticidades ingreso y desigualdad de la pobreza en áreas urbanas y rurales de los estados brasileños: un enfoque espacial. Revista Cepal, 129, 79-98.

Tabosa, F. J. S., Castelar, P. U. C., \& Irffi, G. D. (2016). Brasil, 1981-2013: efectos del crecimiento económico y de la desigualdad de los ingresos en la pobreza. Revista De La Cepal, 120, 163-180.

Tabosa, F. J. S., Irffi, G., \& Guimarães, D. B. (2014). Elasticidades renda e desigualdade da pobreza no Nordeste de 1981 a 2009. Revista De Política Agrícola, 23(1), 65-76.

Tochetto, D. G., Ribeiro, E. P., Comim, F. V., \& Porto, S. S., Jr. (2004). Crescimento Pró-Pobre No Brasil Uma Análise Exploratória. In Anais do $32^{\circ}$ Encontro Nacional De Economia, João Pessoa, PB. 


\section{Helson Gomes de Souza}

https://orcid.org/0000-0001-7873-3798

Ph.D. student in Applied Economics (PPGE/UFPB); Substitute professor at the Center for Higher Studies of Codó (CESCD) at the State University of Maranhão. E-mail: helson.g.souza@gmail.com

\section{Francisco José Silva Tabosa}

https://orcid.org/0000-0003-1280-8907

Ph.D. in Economics from the Federal University of Ceará (UFC); Adjunct Professor of the Postgraduate Program in Rural Economics at the Federal University of Ceará (UFC). E-mail: franzetabosa@ufc.br

\section{Jair Andrade de Araújo}

https://orcid.org/0000-0001-6297-9558

Ph.D. in Economics from the Federal University of Ceará (UFC); Adjunct Professor of the Postgraduate Program in Rural Economics at the Federal University of Ceará (UFC). E-mail: jairandrade@ufc.br

\section{Pablo Urano de Carvalho Castelar}

https://orcid.org/0000-0001-9990-7873

Ph.D. in Economics from the Federal University of Ceará (UFC); Adjunct Professor of the Finance Course at the Federal University of Ceará (UFC). E-mail: pcastelar@ufc.br 


\section{APPENDIX}

\section{TABLE 3 AVERAGE OF THE DYNAMIC ELASTICITIES FOR THE URBAN AND RURAL AREAS OF THE BRAZILIAN REGIONS}

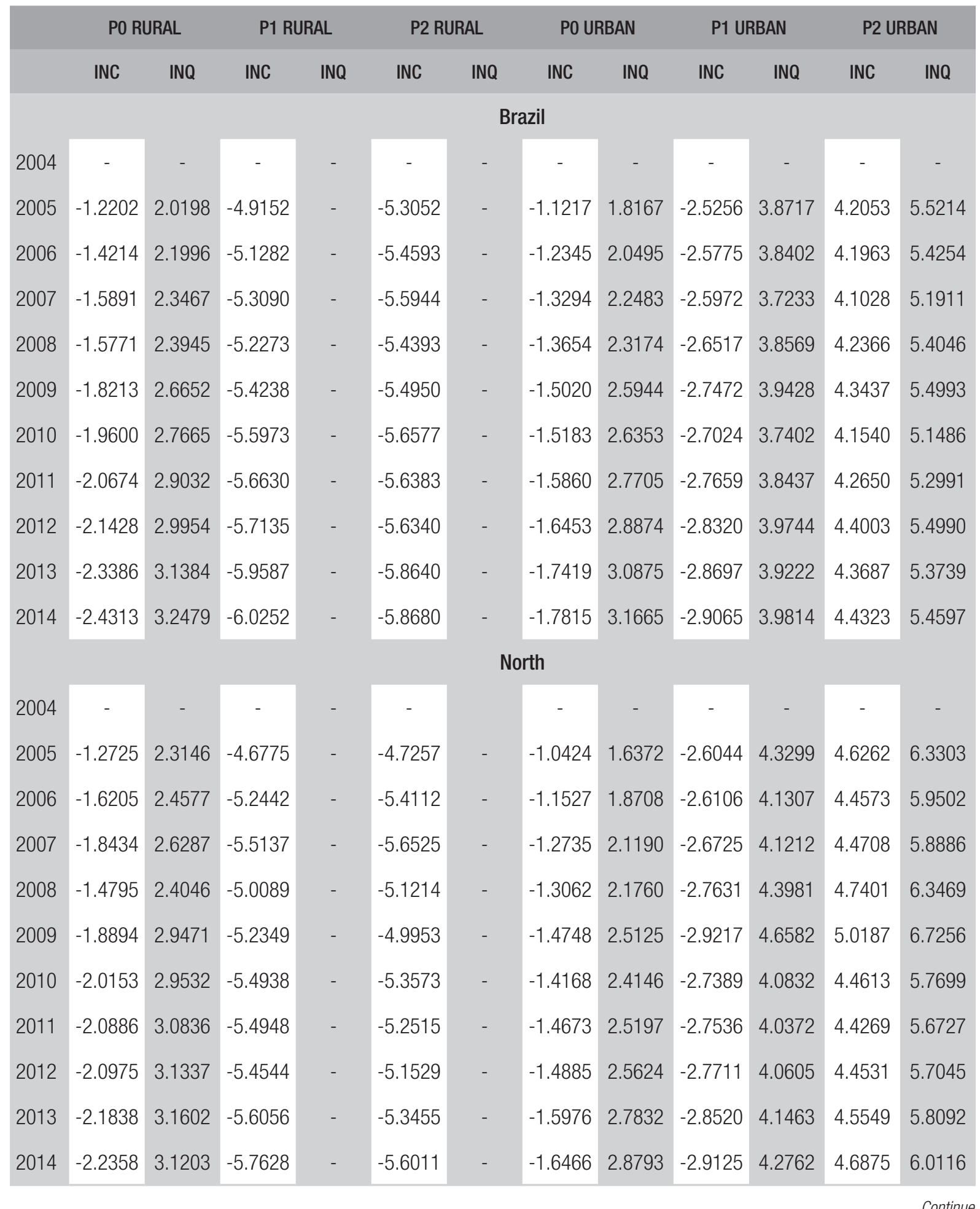


RAP | A spatial analysis of how growth and inequality affect poverty in Brazil

\begin{tabular}{|c|c|c|c|c|c|c|c|c|c|c|c|c|}
\hline & \multicolumn{2}{|c|}{ PO RURAL } & \multicolumn{2}{|c|}{ P1 RURAL } & \multicolumn{2}{|c|}{ P2 RURAL } & \multicolumn{2}{|c|}{ PO URBAN } & \multicolumn{2}{|c|}{ P1 URBAN } & \multicolumn{2}{|c|}{ P2 URBAN } \\
\hline & INC & INQ & INC & INQ & INC & INQ & INC & INQ & INC & INQ & INC & INQ \\
\hline \multicolumn{13}{|c|}{ Northeast } \\
\hline 2004 & - & - & - & - & - & - & - & - & - & - & - & - \\
\hline 2005 & -0.4761 & 0.9106 & -4.6522 & - & -5.8452 & - & -0.7409 & 1.0419 & -2.2760 & 3.6954 & 3.9669 & 5.3651 \\
\hline 2006 & -0.6168 & 1.1626 & -4.6519 & - & -5.6374 & - & -0.8895 & 1.3403 & -2.4012 & 3.8694 & 4.1510 & 5.6050 \\
\hline 2007 & -0.7081 & 1.2987 & -4.6840 & - & -5.5709 & - & -0.9661 & 1.5102 & -2.3502 & 3.5216 & 3.8435 & 4.9848 \\
\hline 2008 & -0.8405 & 1.4931 & -4.7344 & - & -5.4823 & - & -1.0159 & 1.6048 & -2.4327 & 3.7333 & 4.0541 & 5.3261 \\
\hline 2009 & -1.0559 & 1.7436 & -4.8940 & - & -5.5025 & - & -1.1560 & 1.8894 & -2.5275 & 3.8094 & 4.1524 & 5.4027 \\
\hline 2010 & -1.1557 & 1.8317 & -4.9946 & - & -5.5725 & - & -1.1854 & 1.9576 & -2.4869 & 3.5961 & 3.9552 & 5.0290 \\
\hline 2011 & -1.2949 & 1.9763 & -5.1244 & - & -5.6375 & - & -1.2545 & 2.0933 & -2.5670 & 3.7601 & 4.1239 & 5.2818 \\
\hline 2012 & -1.4017 & 2.0718 & -5.2375 & - & -5.7194 & - & -1.3150 & 2.2103 & -2.6505 & 3.9543 & 4.3198 & 5.5891 \\
\hline 2013 & -1.6748 & 2.2621 & -5.5902 & - & -6.0628 & - & -1.4232 & 2.4352 & -2.6872 & 3.8749 & 4.2644 & 5.4134 \\
\hline \multirow[t]{2}{*}{2014} & -1.7068 & 2.4566 & -5.4281 & - & -5.6728 & - & -1.4700 & 2.5289 & -2.7301 & 3.9426 & 4.3375 & 5.5109 \\
\hline & & & & & & \multicolumn{2}{|c|}{ Southeast } & & & & & \\
\hline 2004 & - & - & - & - & - & - & - & - & - & - & - & - \\
\hline 2005 & -1.6742 & 2.6130 & -5.1745 & - & -5.1845 & - & -1.4773 & 2.5535 & -2.6638 & 3.6768 & 4.0862 & 5.0564 \\
\hline 2006 & -1.7377 & 2.6543 & -5.2599 & - & -5.2716 & - & -1.5401 & 2.6890 & -2.6503 & 3.4989 & 3.9287 & 4.7302 \\
\hline 2007 & -2.0402 & 2.7940 & -5.7534 & - & -5.8563 & - & -1.6354 & 2.8850 & -2.6971 & 3.4835 & 3.9318 & 4.6682 \\
\hline 2008 & -2.1512 & 2.9395 & -5.7972 & - & -5.7986 & - & -1.7033 & 3.0142 & -2.8069 & 3.7621 & 4.2093 & 5.1163 \\
\hline 2009 & -2.3040 & 3.0994 & -5.9314 & - & -5.8572 & - & -1.8145 & 3.2430 & -2.8605 & 3.7406 & 4.2095 & 5.0379 \\
\hline 2010 & -2.4593 & 3.1966 & -6.1450 & - & -6.0801 & - & -1.8341 & 3.2871 & -2.8439 & 3.6383 & 4.1159 & 4.8565 \\
\hline 2011 & -2.5998 & 3.3941 & -6.2090 & - & -6.0082 & - & -1.8938 & 3.4045 & -2.9115 & 3.7736 & 4.2556 & 5.0641 \\
\hline 2012 & -2.7082 & 3.5403 & -6.2654 & - & -5.9680 & - & -1.9567 & 3.5286 & -2.9809 & 3.9094 & 4.3964 & 5.2713 \\
\hline 2013 & 2.8282 & 3.5897 & -6.4607 & - & -6.2040 & - & -2.0332 & 3.6926 & -2.9710 & 3.7177 & 4.2284 & 4.9167 \\
\hline 2014 & -2.8382 & 3.7887 & -6.2468 & - & -5.7372 & - & -2.0652 & 3.7539 & -3.0207 & 3.8408 & 4.3514 & 5.1139 \\
\hline
\end{tabular}


RAP | A spatial analysis of how growth and inequality affect poverty in Brazil

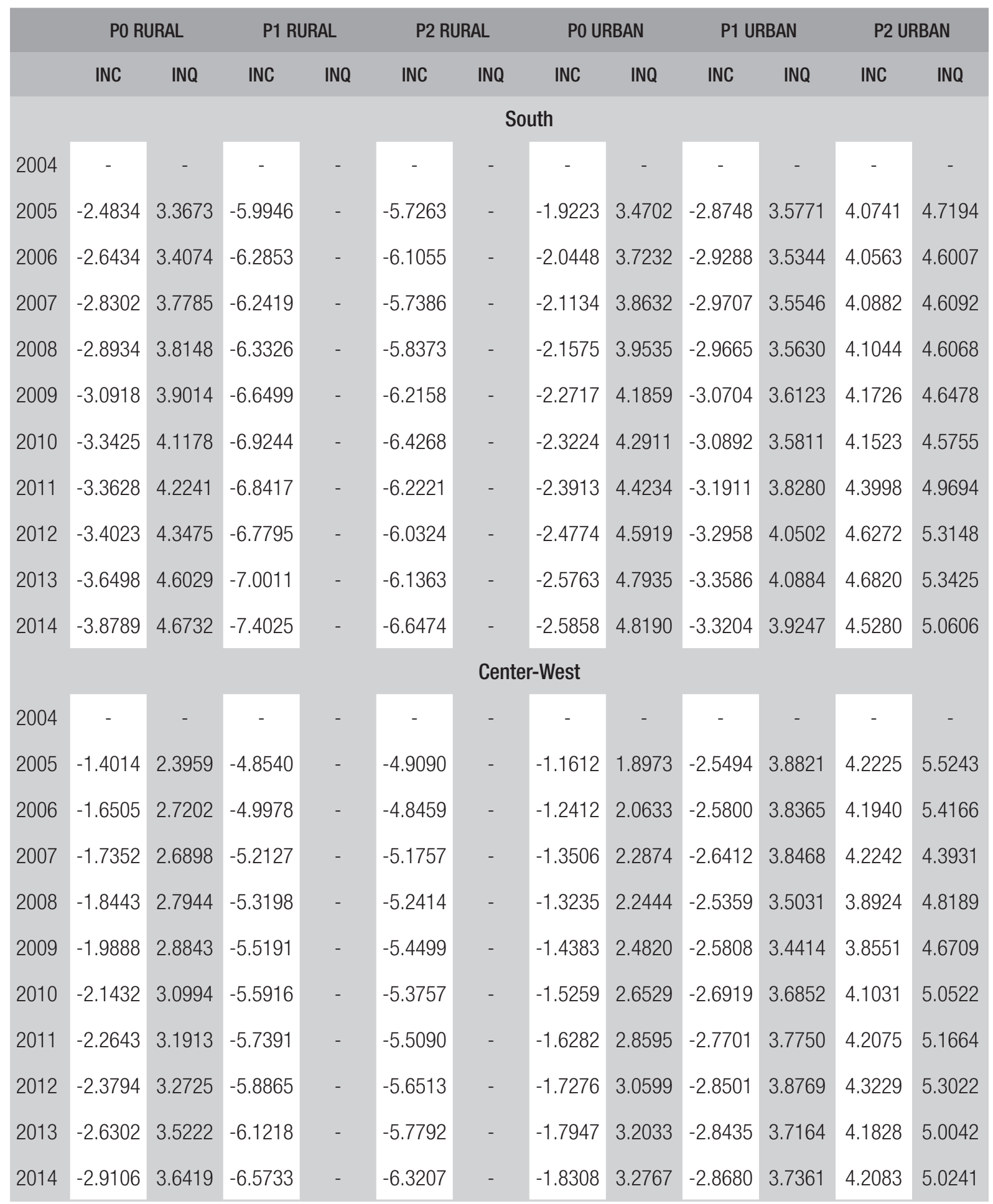

Note: INCE = Income Elasticity; INQE = Inequality Elasticity.

Source: Elaborated by the authors. 